\title{
Private Sector Development and Economic Diversification: Evidence from Nigeria
}

\author{
Innocent Chukwuka Ogbonna \\ Department of Economics, Ebonyi State University, Abakaliki
}

\begin{abstract}
Nigerian economy is monolithic with primary commodity oil export constituting above 95 per cent of total export receipts since the 1990s. This feature has its implications on the economy as the vagaries associated with oil export are transmitted directly to the economy. Recently, economists argue in favour of economic diversification, that is, one with expanded varieties of determinants of income and employment, as key to erecting a sustainable growth and development. In fact, economic diversity and economic development are linked since the former provides opportunities for income growth, employment and development which a mono-product economy lacks. Notwithstanding attempts towards attaining a more diversified economy, this has not translated into commensurate employment, infrastructural provision and sustained advancement in the standard of living due to limited market assess, unskilled labour, insecurity, corruption, etc. This study seeks to examine empirically the relationship between private sector development and economic diversification from 1999Q1-2016Q4. Employing time series analysis with data drawn from Nigeria, the results indicate that the level of private sector investment is a significant determinant of economic diversification both in the short- and long-run. Equivalently, quality of infrastructure, violent conflicts, quality of governance, and openness are also important determinants of economic diversification in the short- and long-run.
\end{abstract}

Key words: economic diversification, private sector development, infrastructure, ARDL,

\section{INTRODUCTION}

Broadly speaking, it is believed that a diversified economy - one with expanded varieties of determinants of income and employment - is relatively more stable and less sensitive to the wider fluctuations associated with economies with one or few industries. While diversification shield economies from extreme vicissitudes of cyclical actions since risk is equally distributed across wider range of industries, an economy anchored on one or few industries has its risk concentrated on a handful of industries. Berthelemy and Chauvin, (2000)[1] argue that economic diversification is the expansion of production over many sectors. For Ali, Alwang and Siegel, (1991)[2] it is the variation in the spread of a country's existing product mix. With diversification, stronger and well performing industries will support the economy to maintain healthy growth through compensatory employment generation even if some other industries perform below installed capacity. This is why some economists and policy makers argue that diversification is employment insurance with diversified economy providing more employment during fluctuations. It is also debated that diversification promotes resilience, especially to exogenous episodes and developments.

Although Nigerian economy has exhibited significant advancement in her output growth in nearly two decades gone by, this has not translated into commensurate employment, adequate infrastructural provision and sustainable advancement in the standard of living of the people. These attributes have challenging implications for past and present governments and policy makers in Nigeria. Consequently, contemporary security challenge with international links has emerged as a result of the dehumanising factors confronting the people (Ekpo, Afangideh, and 
Udo, 2014)[3]. Nigeria's economic performance in the period 1999-2016 was decidedly impressive with real output growth rate averaging 6.44 per cent per annum. Specifically, between 1999-2004 average annual output growth rate was 7.88 per cent, but fell marginally to an average of 7.43 per cent between 2005-2010 and further to an annual average of 4.09 per cent in the 2011-2016 period (figure 1).

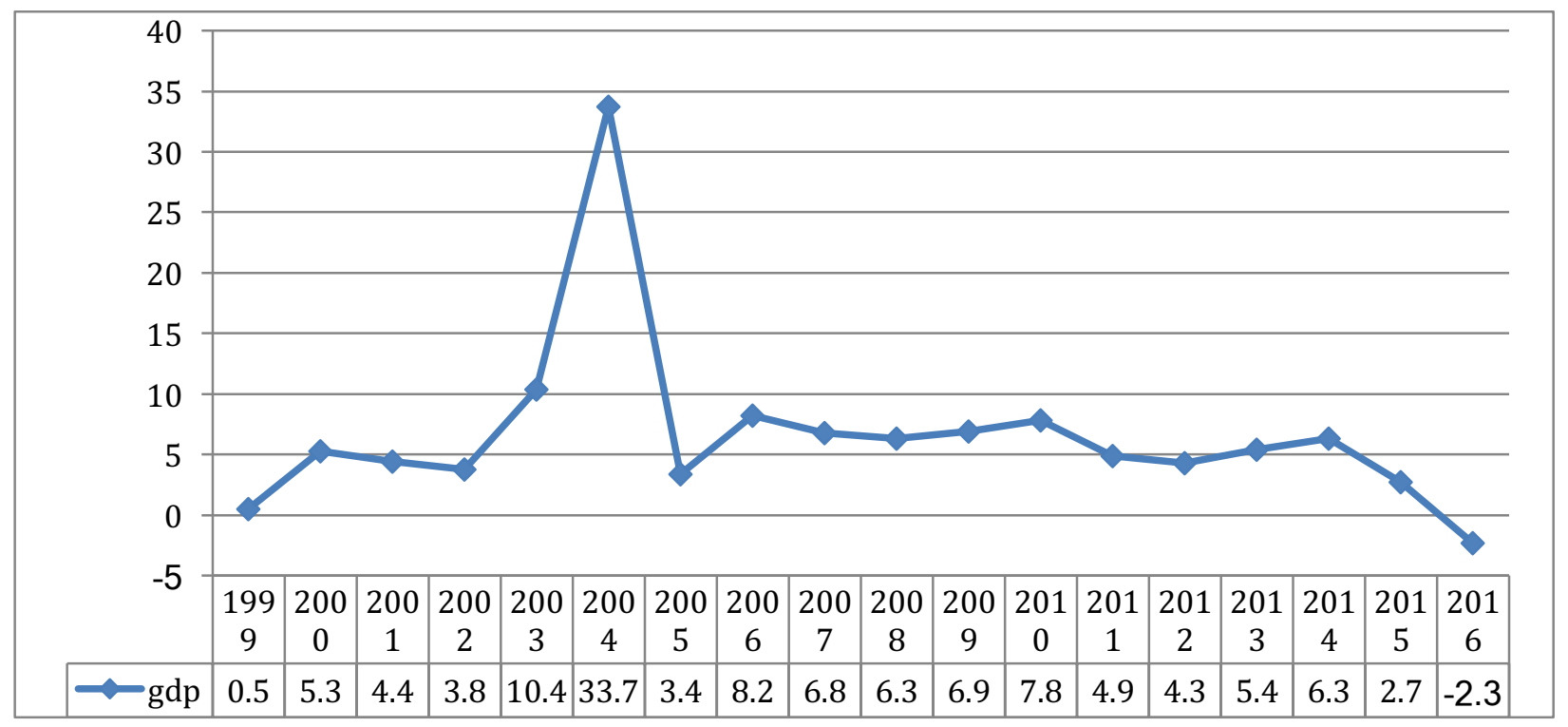

Figure 1: Average annual growth of output in Nigeria (1999-2016)

A major feature of the Nigerian economy is that the growth dynamics have been fundamentally and disproportionately driven by the primary sector - existence and exploitation of extractive industry and subsistence agriculture with no remarkable value addition - with the bulk of export revenue coming from oil resource which is finite and its price exogenously determined. This characteristic makes the country's economy vulnerable to the alternation of her trading partners and more often these economies transmit exogenous shocks that usually expose the domestic economy to unfavourable economic consequences that have implications for economic growth, stability and development.

As a result, from the resource-rich country approach, especially in the developing economies, economic diversification may assist solve some economic issues. First, it is expected to shield the economy from the boom and bust cycles associated with volatility-prone demand and price of primary commodity exports. Second, it is expected to neutralize the "Dutch Disease" effect of natural resources (Ekpo, et al, 2014)[3]. Unlike some modern resource-rich economies such as Netherlands, Canada, Australia, etc where oil exploitation and exportation is seen as additional economic activity, it is treated uniquely as the only source of wealth in Nigeria, and oil revenue instead crowds out other economic activity. Economic diversification will help expand other determinants of sources of employment and income, and hence eliminate or at least reduce overdependence on a single source of income. Third, oil resource is finite and economic diversification is among the approaches to ensure variation in the country's product mix and hence guarantee economic growth and sustenance even in a post-oil economy. Finally, the persistent civil conflicts, terrorism, militancy and secessionist tendencies which are linked to overdependence on oil resource in Nigeria may abate with successful diversification that would expand peoples' choices, create employment opportunities and growth of income.

It has been argued that for diversification to succeed, collaboration between the public and private sectors is essential. While the critical role of the private sector towards economic growth, development, and job creation is acknowledged, the achievement of this role is 
anchored on the complementary role of the public sector, namely, adequate infrastructural provision, strong institutions and financial markets, and massive investment.

Structurally, this introduction is followed by section two which highlights the stylized facts about Nigerian economy. Section three reviews related literature, section four discusses data and methodology, section five highlights empirical results and discussion, while section six presents the recommendation and conclusion.

\section{STYLIZED FACTS ABOUT NIGERIAN ECONOMY}

The trend of economic diversification of the Nigerian economy is compared with the diversification of some selected West African countries and presented in table 1 and figure 2 . It is noteworthy to observe that Nigeria was the least diversified economy both among the selected West African countries and Africa. This may be linked to two reasons. First, the monolithic structure of the economy where oil export revenue earnings have remained above 95 percent of total export earnings and fiscal revenue since the 1990s. Second, accruals from exports were not effectively channelled towards growth inducing economic sectors due to poor implementation of economic policies, endemic corruption, and weak institutions. Given the country's low diversification index, Nigeria is in dire need of economic diversification away from single primary commodity production and export, and policies to increase and expand production over many sectors are imperative. In this regard, the private sector's role in diversifying the economy through entrepreneurial skill, innovation and efficient investment should be explored. The evolution of entertainment industry and information technology (ICT) both driven by the private sector are cases in point. Both sectors play a major role in fighting unemployment, violent conflicts and terrorism and serve as major foreign exchange earner. However, despite innovative and entrepreneurial spirit of the private sector, government role to provide infrastructure and enabling environment would equally prosper development efforts. In this case, the recent donation of $\$ 200$ million to develop the entertainment industry is a step in the right direction. It is argued that more is expected from the government to develop and sustain the entertainment industry, especially regarding regulatory legislation, necessary infrastructural provision and capacity building that would reposition the industry for foreign exchange. As a result of the long term requirement of diversification programme the private sector's leading role in production is expected to manifest evidently in investment in research and development, innovation and technical knowhow.

Table 1: Diversification Index for Selected ECOWAS Countries and Africa (2007-2015)

\begin{tabular}{|c|c|c|c|c|c|c|c|c|c|c|c|}
\hline & \multirow{2}{*}{\multicolumn{9}{|c|}{ Diversification Index for Selected West Countries }} & \multirow[b]{3}{*}{$\begin{array}{c}\text { Averag } \\
\text { e }\end{array}$} & \multirow[b]{3}{*}{ Africa } \\
\hline \multirow[b]{2}{*}{ Year } & & & & & & & & & & & \\
\hline & Benin & $\begin{array}{l}\text { Côte } \\
\text { d'Ivoire }\end{array}$ & Gambia & Ghana & Guinea & Nigeria & Senegal & $\begin{array}{l}\text { Sierra } \\
\text { Leone }\end{array}$ & Togo & & \\
\hline 2007 & 7.8 & 8.5 & 8.6 & 4.5 & 3.7 & 1.3 & 26.2 & 7.5 & 10.6 & 8.7 & 4.3 \\
\hline 2008 & 8.1 & 9.0 & 3.8 & 5.0 & 3.5 & 1.3 & 10.7 & 9.1 & 5.8 & 6.3 & 3.8 \\
\hline 2009 & 7.0 & 6.6 & 5.0 & 4.0 & 2.5 & 1.3 & 13.6 & 13.2 & 7.2 & 6.7 & 5.2 \\
\hline 2010 & 6.1 & 7.7 & 10.8 & 4.4 & 5.1 & 1.4 & 10.2 & 8.5 & 10.6 & 7.2 & 4.7 \\
\hline 2011 & 7.1 & 6.5 & 7.8 & 5.7 & 4.5 & 1.4 & 12.8 & 9.5 & 11.0 & 7.4 & 3.0 \\
\hline 2012 & 5.9 & 8.8 & 4.1 & 5.0 & 4.3 & 1.4 & 11.8 & 4.0 & 7.5 & 5.9 & 3.1 \\
\hline 2013 & 5.6 & 8.6 & 3.5 & 5.6 & 4.2 & 1.4 & 11.9 & 1.9 & 6.9 & 5.5 & 3.3 \\
\hline 2014 & 5.5 & 7.3 & 4.7 & 5.2 & 3.7 & 1.5 & 13.0 & 1.8 & 7.5 & 5.6 & 3.5 \\
\hline 2015 & 6.0 & 5.9 & 3.3 & 4.3 & 3.6 & 1.6 & 14.6 & 6.4 & 11.6 & 6.4 & 4.9 \\
\hline
\end{tabular}

Source: Data for 2011-2015 were from AfDB Statistics Dept, COMTRADE Database (Harmonized System 2002) - UN Statistics Division. Data for 2007-2010 were from African Economic Outlook, 2012 in Ekpo, et al 2014[3] 


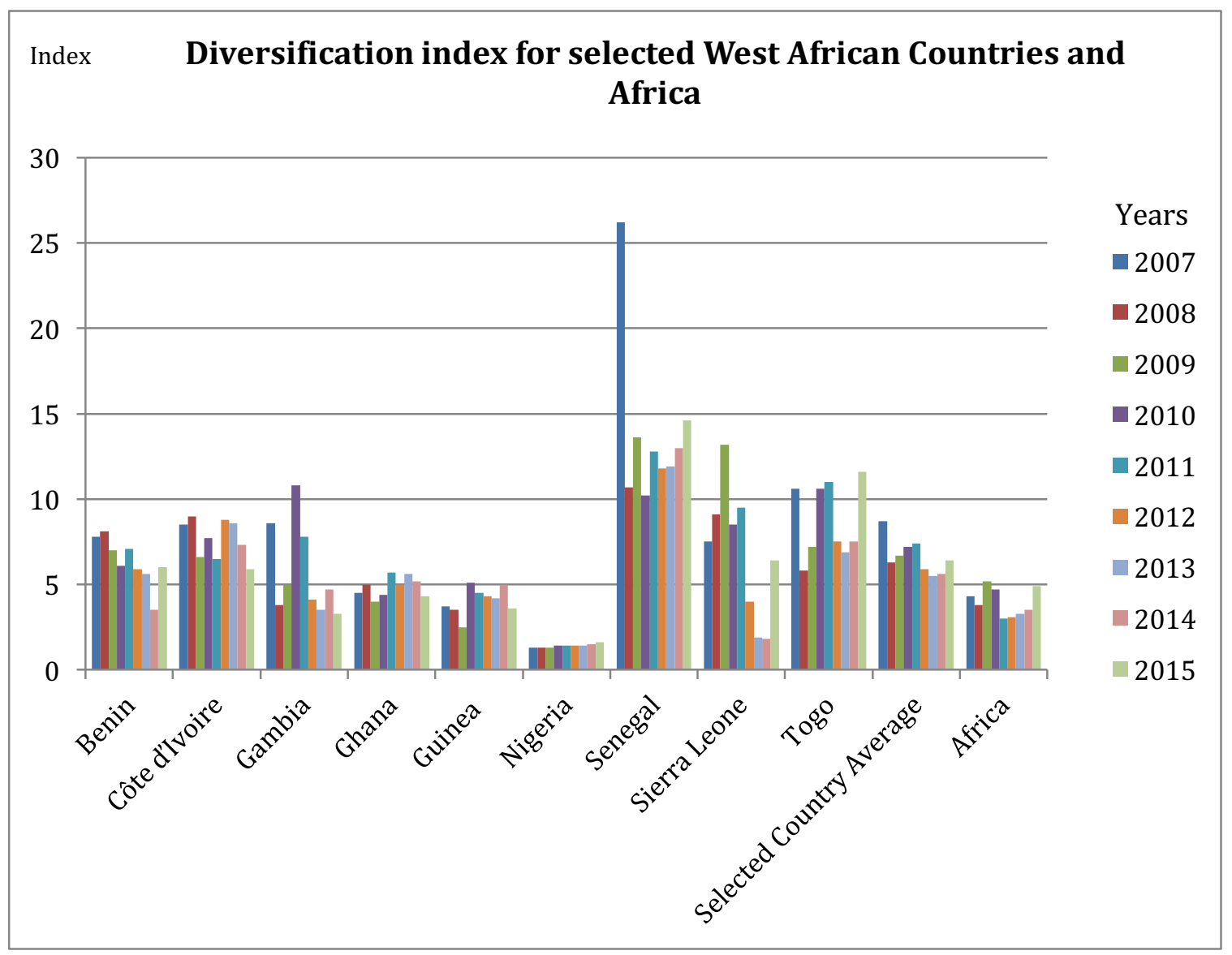

Source: Data for 2011-2015 were from AfDB Statistics Dept, COMTRADE Database (Harmonized System 2002) - UN Statistics Division. Data for 2007-2010 were from African Economic Outlook, 2012 in Ekpo, et al 2014[3]

Figure 2: Diversification Index for Selected ECOWAS Countries and Africa (2017-2015)

\section{Theories of Diversification}

\section{REVIEW OF RELATED LITERATURE}

The pioneering work on economic diversification was undertaken by MacLaughlin (1930)[4] in an attempt to explain the economic crises that engulfed American cities in the 1930s as a result of inter-war period. Using the degree of concentration of economic activities to explain economic cycles in America, he found that cities with higher level of concentration suffered the crises more than the rest. Afterwards, Rosenstein Rodan and Leontief conceptualized how the concentration of inter-sectoral matrices jointly drive and multiply developing economies' internal trade. These debates on the relationship between cumulative drive and the catalytic role of industries remain a major topic for debate up to the 1970s. These raging debate equally highlighted the role of diversification in mitigating economic vicissitudes (Massel (1970)[5], especially movements in raw material prices in developing economies.

Kuznets (1966)[6] and Rostow (1960)[7] separately discussed the importance of structural transformation and diversification in economic development and growth process. They presented series of elements necessary to transform and strengthen the productive system of any traditional economy. Firstly, massive capital accumulation (investment) was considered an essential element in the diversification and transformation of developing economies. Their literatures largely concurred with the discussions on sectroral priorities which formed important discussion on diversification by the first generational writers. So, if the idea of balanced growth matter in some quarters, greater emphasized the idea that structural transformation of sectors even matter more for a cumulative role for the rest of the economy 
(Hirschman, 1958)[8]. Equally important like massive capital accumulation and sectoral policies is the role of industry as suggested by earlier works on diversification. Indeed, earlier works on diversification had hypothesized that industrial development would transform traditional economies and modernize the productive structures of developing economies. Indeed, earlier works on economic development strategies emphasized diversification - series of choices to be implemented - and analytical tools such as input-output matrices to measure progress towards diversification. Further, these generations of first works sought to identify the main drivers of diversification process and concluded that investment and industrial development (sectoral policy) are the main drivers. Eventually, discussion on diversification was marginalized as a result of the economic crises at the end of the 1970 and the failure of import substitution strategies to improve the economic fortunes of developing countries led to the replacement of diversification debate with reflections on macroeconomic stabilization and international specialization.

But sooner than later, however, renewed discussion on diversification dominated economic policy debate. Many factors are responsible. First, the weak growth prospects recorded in many regions, particularly in Africa. Second, the failure of African countries to benefit from favourable trade options granted them by most developed nations, and third, the limited gains to be derived from the Doha Round as shown by many studies undertaken (ECA, 2004)[9]. Studies show that supply inhibitions and undiversified African economies are responsible for the low benefits recorded from favourable international trade options accorded to Africa.

The renewed debate on diversification by economists sought to come into historical advancement of the open tradition in the discussion on diversification. The new theoretical interest concerns the factors necessary for a successful diversification of productive composition of economies. The new inquiry has more benefit compared to studies conducted four decades ago because it can compare experiences of developing nations in the last three decades (Gutierrez de Pineres and Ferrantino, 1971)[10].

Recent studies acknowledge many determinants to clarify diversification process, especially in Africa. The first is related to the level of output in an economy. Imbs and Waciag (2003)[11] in a study that emphasized macroeconomic aspects show that diversification has an inverted Ushaped link with level of development. Accordingly, diversification increases with economic development, measured by per capita revenue, then decreases with a turning point. Another important determinant of diversification is investment, which is a positive factor of productive growth and rise in productivity of novel economic sectors. From this view point, the historical background of developing nations reveals that an increase in investment usually leads to a rise in the diversification of volume of output. Recent literature also emphasize the role of sectoral policy in the diversification struggle where industrial development constitute the main restoration of industrial policy discuss. As the entire world gets more integrated through globalization drive, industrialization, especially by developing countries must constitute the major diversification strategy to consolidate international integration and competition. Historical experience reveals how industrial development assists national economies in their diversification efforts and the role of industrialization as growth driver with potential to improve international competitiveness of national economies. Several studies also show other determinants of diversification such as new technologies and additional foreign markets. These studies add to historical experience to emphasize the relationship between economic diversification process and advancement in global competition. In fact, historical experience shows that successful countries in terms of output growth and international competition are those, who, in the last three decades have maintained high investment rate particularly in the 
industrial sector. The high rate of investment strengthens their economies admittance and access to new technologies, productivity improvement and international competition.

According to ECA (2004)[9], trade policy also plays a major role in economic diversification efforts. However, according to Hammouda, et al (2006)[12], trade policies in Africa is not dynamic and constantly gives linear influence on some industrial enterprise that are not advantageous to the advancement of competition for African economies (Hammouda, et al 2006)[12].

Different authors argue in support of the link between diversification and growth. Romer endogenous growth model emphasizes the benefits and significance of diversification by stressing how additional inputs within an economy may assist increase marginal product of labour and human capital (Berthelèmy and Söderling, 2001)[13]. Diversification can also promote growth by expanding and increasing the number of sectors, and hence, investment options and reduction in investor's risks (Acemoglu and Zilibotti, 1997)[14]. Some authors also argue in favour of diversification as promoter of economic growth through the stabilization of export proceeds. They argue that depending on only one product which result from specialization is a major source of volatility and instability and suggest different diversification strategies so as to reduce investors' risks. Most of these works show the link between diversification and stable export revenue and how this can lead to the sustenance of positive change in growth.

Ekpo et al (2014)[3] the series of determinants of diversification and grouped them into five different categories of variables. The first is physical factors such as investment growth and human capital. The second category is linked to policy decisions, that is, impact of trade and industrial policies in securing industrial structure and hence the diversification struggle. The third relates with the macroeconomic variables, namely, exchange rates, inflation rates and major macroeconomic maladjustments. The fourth set is related with institutional variables like conflicts, governance issues, and investment environment. Lastly, the category here is linked to market access which has implications for diversification related policies, particularly through the removal of high and escalating tariffs for developing countries' exports to developed countries.

\section{Empirics on Diversification}

Ekpo, et al (2014)[3] in their attempt to fully model private sector development and economic diversification - evidence from 15 West African (WA) states - using panel data analysis with data drawn from WA countries over the period 1980 to 2012 obtained a particularly worrisome result. Even though the coefficient of the physical variable such as economic growth appears with correct sign, it was negative and statistically insignificant. Again, the institutional variable such as quality of governance was also negative and insignificant. Apart from these, data for the main explanatory variable - the private sector development proxied by private investment - was not available for all the years except for 2011. This is a strong limitation that could affect the result of the analysis and hence policy implications drawn from the study.

Hammouda, et al (2006)[12] in a study titled "diversification: towards a new paradigm for Africa's development" sought to model the determinants of economic diversification in Africa. Using both physical, policy, institutional, and macroeconomic variables, the results show that most of the important variables were not statistically significant. Apart from this, the coefficients of physical variables such as investment and per capita income, and policy variables such as openness and industrial production appeared with wrong signs. In addition 
to these worrisome results, the study used only four countries to represent the entire African continent. Serious policy implications and generalizations could not be drawn from the study.

In a study titled, Growth, Productivity and Diversification in Africa, Hammouda, Karingi, Njuguma and Jallab (2010)[15] investigated the relationship among economic growth, productivity and diversification and found that deepening diversification raises total factor productivity (TFP) in Africa. Accordingly, they argue that African countries can scale up the growth of their economies by raising TFP via promoting diversification-enhancing policies.

\section{Gap in Literature}

Studies on private sector development and economic diversification are yet scanty and were mostly carried out using cross sectional or panel data approach. The diversification index estimates of such studies for individual developing countries were obtained from crosssectional data and hence countries were analysed as random observations. The uniqueness and peculiarities of individual developing countries were given little or no attention.

Again, the author is unaware of any empirical studies that utilized time series data and specifically examined the dynamic response of diversification index to private sector development in Nigeria. This work is, thus, a pioneer empirical effort to fill this gap in economic literature. We expect that this study will deepen our knowledge of the phenomenon of private sector development and economic diversification in Nigeria.

\section{METHODOLOGY AND DATA}

The literature review exposed the determinants of economic diversification to include physical, institutional, macroeconomic and policy variables. Some of these factors include, GDP per capita, industrial production index, trade openness, political instability, quality of governance, level of both public and private investment. Following the pioneering works by Hammouda, et al (2006)[12], Ekpo et al (2014)[3], the main objective of this study is to evaluate the impact of private sector development on economic diversification in Nigeria. To achieve this we specify a general model of the form:

$$
\text { DIV }=f(P S I, X i)
$$

Where DIV = Diversification Index; PSI $=$ Private Sector Development; $\mathrm{Xi}=\mathrm{a}$ set of control variables

In Keynesian postulation, the idea of mixed economic system was proposed. In the short run, government was expected to formulate policies that would be effective. But in the long run, the private sector is expected to be a major player. This means that for sustainable economic growth and development, both the public and private sector must participate. Accordingly, economic diversification demands policies both in the short run and in the long run. Public investment in infrastructure is required to promote private capital accumulation in the form of private investment. In this study, the proxy for private sector development is private investment. The size of private investment in an economy may serve to gauge the level of private sector development. A higher private investment is expected to promote the rate of economic diversification.

Other factors that affect economic diversification within the Xi vector include: government infrastructural provision, political instability and conflicts, quality of governance, and openness. As earlier said, public infrastructure is needed to diversify the economy, hence, both variable are expected to relate positively. Good governance is also anticipated to propel 
growth and diversification; hence we expect a positive nexus between them. On the other hand, political instability and conflicts retard growth and diversification. Thus, both variables are expected to relate negatively. Openness is expected to raise exports and hence promote growth and economic diversification. We may therefore specify the econometric relationship between economic diversification and its determinants as:

$$
\begin{aligned}
\text { DIV } & =a_{i}+\beta_{1} \mathrm{PSI}+\beta_{2} \mathrm{PIF}+\beta_{3} \mathrm{GOV}+\beta_{4} \mathrm{CFL}+\beta_{5} \mathrm{OPN}+\mathrm{e}_{\mathrm{it}} \\
\beta_{1}, \beta_{2}, \beta_{3}, \beta_{5}>0 ; & \beta_{4}<0
\end{aligned}
$$

where DIV, PSI are as earlier defined. PIF represents government infrastructural provision proxied by government capital expenditure, GOV stands for quality of governance proxied by Corruption Perception Index (CPI), CFL represents conflict and is estimated as the number of violent protest. OPN stands for openness measured as ratio of total trade to GDP. $e_{t}$ is the error term. The model is estimated using Autoregressive Distributed Lag (ARDL) bounds testing methodology proposed by Pesaran, Shin and Smith (2001)[16]. ARDL has several advantages. First, not minding the order of integration of the variables, it is consistent in estimating the long run relationship. Results of the regular conventional cointegration tests are biased if the vectors in the model were integrated of different orders. Second, different variables can be assigned different lag-lengths as they enter the model (Giles, 2013)[17]. Third, according to Nell (2001)[18], ARDL test includes dynamic estimators of both the short- and long-run coefficients. Fourth, the test produces a more appropriate and robust result even with a small sample size. The general ARDL bound test is estimated:

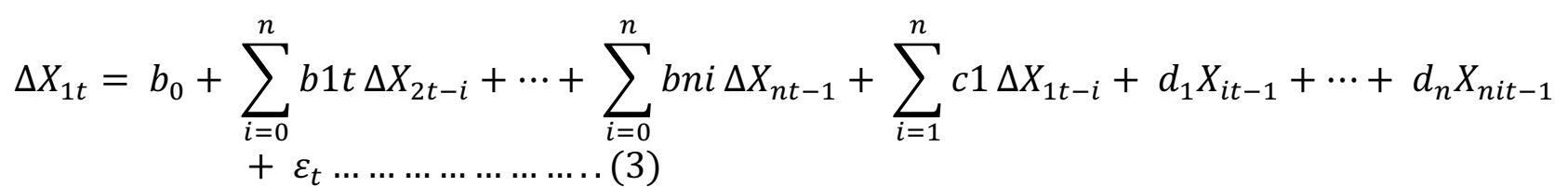

We then conducted F-statistic based bound test to analyze whether or not there exists a longrun relationship. The null hypothesis of no cointegration among the series was: $H_{0}: d_{1}=d_{2}=$ $\mathrm{d}_{3}=\cdots \mathrm{d}_{7}=0$. The null hypothesis is rejected if the computed F-statistic is higher than the upper bound critical value, and thus conclude that there is long-run equilibrium among the variables. However, if the computed F-statistic is lower than the lower bound critical value, the null hypothesis is accepted indicative that there is no long-run relationship among the variables. The result would be inconclusive if the F-statistic obtained falls between the bounds. Annual data was utilized but converted to quarterly data using E-Views version 9. Sample period from 1999Q1 to 2016Q4 was adopted to guarantee enough data points for the econometric analysis and ensure there is no loss of degree of freedom. Data on Diversification Index (DIV) was sourced from AfDB Statistics Department, COMTRADE Database 2016[19], Corruption Perception Index (CPI) and Violent Conflict (CFL) were sourced from tradingeconomics.com $>$ Nigeria[20], Openness (OPN) (total trade as ratio of GDP) was sourced from WDI(2017)[21] but calculated by the author, while private investment (PSI) and public infrastructure (PIF) were sourced from CBN Statistical Bulletin for various years[22].

\section{RESULTS AND DISCUSSION}

Spurious and inconsistent results arise when time series data are not subjected to unit root tests. But these problems are avoided when series undergo unit root tests and stationarity are achieved. Table 3 displays the result of ADF unit root tests for all the variables in the model. 
Ogbonna, I. C. (2018). Private Sector Development and Economic Diversification: Evidence from Nigeria. Advances in Social Sciences Research Journal, 5(3) 170-183.

Table 3: ADF Unit Root Test Results

\begin{tabular}{|c|c|c|c|}
\hline Variable & ADF Test Statistics & $5 \%$ Critical Value & Order of Integration \\
\hline DIV & -3.052400 & -2.905519 & $\mathrm{I}(1)^{*}$ \\
\hline PSI & -3.061504 & -2.905519 & $\mathrm{I}(1)^{*}$ \\
\hline PIF & -3.088953 & -2.905519 & $\mathrm{I}(0)^{*}$ \\
\hline GOV & -3.310215 & -2.905519 & $\mathrm{I}(1)^{*}$ \\
\hline CFL & -2.820896 & -2.590262 & $\mathrm{I}(1)^{* *}$ \\
\hline OPN & -3.069615 & -2.908420 & $\mathrm{I}(1)^{*}$ \\
\hline
\end{tabular}

Key: * Stationary at $5 \%$; ** Stationary at $10 \%$.

Source: author's computation using e-views 9

Table 3 shows that five of the six variables emlployed are stationary (integrated) of order one I(1), while only PIF is stationary (integrated) of order zero I(0). Given the mixture of I(0) and I(1) results, we used Bound testing cointegration (ARDL) model. We used this to test for the existence of long run relationship between the variables of interest. The ARDL $(2,6,6,2,6,2)$ selected through Akaike information criterion results are presented in table 4. 
Table 4: Over-Parameterized Output of Private Sector Development and Economic Diversification in Nigeria

\begin{tabular}{|c|c|c|c|c|}
\hline Variable & Coefficient & Std. Error & $\mathrm{t}$-Statistic & Prob.* \\
\hline $\operatorname{DIV}(-1)$ & 1.485929 & 0.129510 & 11.47343 & 0.0000 \\
\hline $\operatorname{DIV}(-2)$ & -0.570101 & 0.128620 & -4.432450 & 0.0001 \\
\hline PSI & 0.035046 & 0.005381 & 6.513376 & 0.0000 \\
\hline PSI(-1) & -0.052406 & 0.010273 & -5.101495 & 0.0000 \\
\hline PSI(-2) & 0.018825 & 0.008986 & 2.094934 & 0.0439 \\
\hline PSI(-3) & $3.69 \mathrm{E}-13$ & 0.006445 & 5.73E-11 & 1.0000 \\
\hline PSI(-4) & 0.030937 & 0.007538 & 4.104214 & 0.0003 \\
\hline PSI(-5) & -0.043022 & 0.010168 & -4.231234 & 0.0002 \\
\hline PSI(-6) & 0.011662 & 0.006832 & 1.706856 & 0.0972 \\
\hline PIF & 0.041311 & 0.010013 & 4.125665 & 0.0002 \\
\hline PIF(-1) & -0.065239 & 0.019651 & -3.319928 & 0.0022 \\
\hline PIF(-2) & 0.021955 & 0.013329 & 1.647159 & 0.1090 \\
\hline $\operatorname{PIF}(-3)$ & $6.36 \mathrm{E}-14$ & 0.004311 & $1.48 \mathrm{E}-11$ & 1.0000 \\
\hline $\operatorname{PIF}(-4)$ & 0.042276 & 0.008602 & 4.914624 & 0.0000 \\
\hline PIF(-5) & -0.063296 & 0.014131 & -4.479067 & 0.0001 \\
\hline PIF(-6) & 0.020977 & 0.009471 & 2.214771 & 0.0338 \\
\hline GOV & -0.155065 & 0.041841 & -3.706087 & 0.0008 \\
\hline $\operatorname{GOV}(-1)$ & 0.228628 & 0.065778 & 3.475760 & 0.0014 \\
\hline $\operatorname{GOV}(-2)$ & -0.081729 & 0.040958 & -1.995416 & 0.0543 \\
\hline CFL & 0.005122 & 0.001015 & 5.045371 & 0.0000 \\
\hline CFL(-1) & -0.008125 & 0.001883 & -4.315477 & 0.0001 \\
\hline CFL(-2) & 0.003586 & 0.001728 & 2.075295 & 0.0458 \\
\hline CFL(-3) & $-3.35 E-14$ & 0.001478 & $-2.27 \mathrm{E}-11$ & 1.0000 \\
\hline CFL(-4) & 0.014405 & 0.001804 & 7.983248 & 0.0000 \\
\hline CFL $(-5)$ & -0.021790 & 0.002622 & -8.310870 & 0.0000 \\
\hline CFL(-6) & 0.008830 & 0.001821 & 4.848890 & 0.0000 \\
\hline OPN & 0.004478 & 0.000982 & 4.560886 & 0.0001 \\
\hline OPN $(-1)$ & -0.006390 & 0.001659 & -3.852666 & 0.0005 \\
\hline OPN(-2) & 0.002324 & 0.000973 & 2.387801 & 0.0228 \\
\hline $\mathrm{C}$ & 0.059305 & 0.029275 & 2.025787 & 0.0509 \\
\hline R-squared & 0.940577 & \multicolumn{2}{|c|}{ Mean dependent var } & 1.193532 \\
\hline Adjusted R-squared & 0.925206 & \multicolumn{2}{|c|}{ S.D. dependent var } & 0.274868 \\
\hline S.E. of regression & 0.007745 & \multicolumn{2}{|c|}{ Akaike info criterion } & -6.577686 \\
\hline Sum squared resid & 0.001980 & \multicolumn{2}{|c|}{ Schwarz criterion } & -5.557146 \\
\hline Log likelihood & 237.1971 & \multicolumn{2}{|c|}{ Hannan-Quinn criter. } & -6.176303 \\
\hline F-statistic & 2691.356 & \multicolumn{2}{|c|}{ Durbin-Watson stat } & 2.242135 \\
\hline Prob(F-statistic) & 0.000000 & & & \\
\hline
\end{tabular}

*Note: p-values and any subsequent tests do not account for model selection.

\section{Source: Author's computation using e-views 9}

Table 4 shows that the coefficients of all the variables, private sector investment (PSI), public infrastructure (PIF), violent conflicts (CFL), and trade openness (OPN), are significantly positive in the determination of diversification, except GOV variable which is significantly negative. However, the coefficients of violent conflict (CFL) and quality of governance (GOV) did not conform to our a priori signs. Specifically, the main physical variable of interest, PSI, is significantly positive in the determination of the index of economic diversification in Nigeria in the period 1991Q1-2016Q4. A 1\% increase in the growth rate of PSI promote economic diversification index by 0.04 unit. This is consistent with the theoretical predictions that private sector development enhances the index of economic diversity. On its part, a 1\% increase in the growth rate of PIF raise Nigeria's economic diversification index to 0.04 unit. 
The probability of the F-statistic is a further proof of the statistical significance of our model. The $\mathrm{R}^{2}$ of $94 \%$ and adjusted $\mathrm{R}^{2}$ of $93 \%$ are indicative that the explanatory variables adequately and substantially explained the changes in the diversification index in Nigeria.

Table 5: The Error Correction and Long Run Representation of Private Sector Development and Economic Diversification in Nigeria (1999Q1-2016Q4)

\begin{tabular}{|c|c|c|c|c|}
\hline \multicolumn{5}{|c|}{ Cointegrating Form } \\
\hline Variable & Coefficient & Std. Error & t-Statistic & Prob. \\
\hline $\mathrm{D}(\mathrm{DIV}(-1))$ & 0.736158 & 0.082499 & 8.923212 & 0.0000 \\
\hline $\mathrm{D}(\mathrm{PSI})$ & 0.003382 & 0.001513 & 2.234809 & 0.0295 \\
\hline $\mathrm{D}(\mathrm{PIF})$ & 0.003640 & 0.001963 & 1.854434 & 0.0690 \\
\hline $\mathrm{D}(\mathrm{GOV})$ & -0.100131 & 0.047043 & -2.128527 & 0.0378 \\
\hline $\mathrm{D}(\mathrm{GOV}(-1))$ & 0.092636 & 0.050752 & 1.825264 & 0.0734 \\
\hline $\mathrm{D}(\mathrm{CFL})$ & 0.000791 & 0.000373 & 2.121580 & 0.0384 \\
\hline $\mathrm{D}(\mathrm{OPN})$ & -0.002594 & 0.001040 & -2.494493 & 0.0156 \\
\hline $\mathrm{D}(\mathrm{OPN}(-1))$ & 0.002011 & 0.001053 & 1.908847 & 0.0615 \\
\hline CointEq $(-1)$ & -0.136507 & 0.028277 & -4.827414 & 0.0000 \\
\hline \multicolumn{5}{|c|}{ Long Run Coefficients } \\
\hline Variable & Coefficient & Std. Error & t-Statistic & Prob. \\
\hline PSI & 0.024774 & 0.008957 & 2.765761 & 0.0077 \\
\hline PIF & 0.026664 & 0.012869 & 2.071903 & 0.0430 \\
\hline GOV & 0.286178 & 0.052175 & 5.484917 & 0.0000 \\
\hline CFL & 0.005793 & 0.002602 & 2.226030 & 0.0301 \\
\hline OPN & -0.001051 & 0.001926 & -0.545631 & 0.5875 \\
\hline $\mathrm{C}$ & 0.160994 & 0.171635 & 0.938005 & 0.3523 \\
\hline
\end{tabular}

Source: Author's computation using e-views 9

\section{The Error Correction and Long Run Representations}

Table 5 shows that both the short run and long run coefficients of the private sector investment (PSI) conform to the theoretical postulation. Ceteris paribus, a percent increase in PSI significantly promotes index of diversification (DIV) by 0.003 unit in the short run and 0.025 unit in the long run. This confirms the theoretical thesis that private sector investment can promote the level of economic diversity. By implication, any policy that encourages private sector development would have a strong positive impact on the index of economic diversification. On its part, the effect of government infrastructure is also positive and significant in the short- and long-run. Economic theory also predicts that public infrastructure can enhance economic diversification. Our result is in tandem with this theoretical prediction. Our findings regarding PSI and PIF are consistent with the results of Ekpo, et al (2014)[3].

In the short run, the coefficient of the variable GOV is again negative and significant while it is positive and significant in the long run.

The result is fascinating given Nigeria's high corruption ranking (low scale in corruption index, hence poor governance). When corruption perception index (GOV) increase by 1 unit in a quarter, diversification index decrease significantly by 10 units in the short run, but significantly increase by 29 units in the long run, all things remaining the same. In other words, 
any policy that strengthened the quality of governance could have led to more specialization than diversification in the short run, but more diversification in the long run.

Another institutional variable in our regression result is the CFL. It is positive and significant both in the short- and long-run. Our result implies that increase in conflicts promoted economic diversification index in Nigeria. The result is inconsistent with our theoretical postulation. Lastly, the policy variable, openness (OPN) was negative and statistically significant in the short run but negative and insignificant in the long run. The implication is that trade liberalization in Nigeria promoted specialization but undermined diversification both in the short- and long-run. Hence, any trade policy aimed at promoting increased trade is a negative determinant of economic diversification index.

The error correction (CointEq(-1)) with negative value 0.14 is correctly signed and significant, and is indicative that 14 percent speed of adjustment back to equilibrium is guaranteed within a quarter.

\section{COEFFICIENT DIAGNOSTICS: ARDL Bound Test}

Table 6: ARDL Bounds Test

\begin{tabular}{lll} 
Test Statistic & Value & $\mathrm{k}$ \\
\hline \hline F-statistic & 3.444294 & 5 \\
\hline \hline
\end{tabular}

Critical Value Bounds

\begin{tabular}{lcc}
\hline \hline Significance & I0 Bound & I1 Bound \\
\hline \hline $10 \%$ & 2.26 & 3.35 \\
$5 \%$ & 2.62 & 3.79 \\
$2.5 \%$ & 2.96 & 4.18 \\
$1 \%$ & 3.41 & 4.68 \\
\hline \hline
\end{tabular}

Source: Computed by the author using e-views 9

F-Statistic bounds test examined whether or not there exists a long run relationship between DIV and the regressors. The null hypothesis is that there is no long run relationship if the FStatistic is higher than the upper bound critical value. Our results show that the computed Fstatistic of 3.44 is higher than the upper bound critical value of 3.35 at 10 percent significant level. We therefore reject the null hypothesis and conclude that long run relationship exists among the series (table 6).

\section{CONCLUSION AND POLICY RECOMMENDATIONS}

The study examined the determinants of economic diversification (DIV) in Nigeria. Specifically, it sought to examine whether private sector investment (PSI) is a significant determinant of diversification in the period 1999Q1 to 2016Q4 so as to provide evidence based policies that would enhance the expansion of production over many sectors for economic growth and development. The use of ARDL bound testing approach in the estimation result indicates that in the short- and long-run, private sector investment significantly promote the index of economic diversification in Nigeria. Equivalently, public infrastructure (PIF) is a positive determinant of diversification both in the short- and long-run, while governance (GOV) highly influences diversification in the long run. However, another fascinating conclusion from our empirical analysis was that in the short run, GOV could have promoted specialization, not diversification, while trade liberalization (OPN) could have promoted 
specialization rather than economic diversification both in the short- and long-run. Another important conclusion is that violent conflicts (CFL) promote specialization rather than diversification both in the short- and long-run.

A major policy recommendation that could be drawn on the basis of the results obtained from this study is the need to provide incentive for private sector investment through favourable monetary and fiscal policies. The role of financial sector in promoting private investment outcomes through credit facilities is critical to its contribution to economic diversity. Policy makers and government alike should come up with more friendly and low-interest yielding credit facilities that could deepen private sector development efforts towards the expansion of economic sectors. Deliberate monetary policy stance aimed to woo banks and non-bank financial institutions to provide medium and long term low credit facilities to private sector is imperative.

Deliberate government policy towards increased infrastructural provision and upgrading of existing infrastructure specifically aimed to advance and expand sectoral choices is paramount. In this regard, different tiers of government should take advantage and develop other sectors of the economy where their comparative advantage is higher. Of special mention is the urgent need to invest heavily and ensure regular supply of electricity. The private sector and indeed all the economic sectors await the full realisation of 24 hours $\mathrm{x} 7$ days power supply.

Another policy recommendation that could be drawn given the linkage between good governance and diversification is the need to intensify the fight against corruption, lack of accountability and transparency. Patriotism and zeal to do-it-right are threatened if those entrusted with power lack transparency and accountability. Development policy makers in Nigeria should aim at expanding the economy's productive base over many sectors by formulating sector-oriented policies and microeconomic reforms that are sector specific.

Given the linkage between diversification and trade liberalization, the study recommends strategic and pragmatic trade policy shifts that are both dynamic and adaptive in pursuit of specific development goals.

\section{References}

Berthelemy, J.C. and Chauvin, S 2000). Structural changes in Asia and growth prospects after the crisis, Centre D'etudes prospectives et d'informations internationalles (CEPII)

Ali, Ridwan, Alwang, Jeffrey, and Siegel, Paul 1991, "Is Export Diversification the Best Way to Achieve Export Growth and Stability? A Look at Three African Countries, The World Bank Policy Working Paper

Ekpo, A.H., Afangideh, U.J., Udoh, E.A. (2014). Private sector development and diversification: evidence from West African States West African Institute for Financial and Economic Management (WAIFEM),

MacLaughlin (1930). Industrial Diversification in American cities, Quarterly Journal of Economics, 45, pp 131-149 Leontief, w (1986). Input-Output economies (2 ${ }^{\text {nd }}$ ed.), Oxford University Press, Oxford

Massel, B.f. (1970). Export instability and economic structure, American economic review, 60(4), pp 618-630

Kuznets, S. (1966). Modern economic growth, Yale University Press, Hew Haven

Rostow, W.W. (1`960). The stages of economic growth: a non communist manifesto, Cambridge University Press, Cambridge

Hirschman, A. O. (1958). The Strategy of Economic Development. New Haven, Conn,: Yale University Press.

Economic Commission for Africa (2004). Trade Liberalization under the Doha Development Agenda: Options and Consequences for Africa, Addis Ababa, Ethiopia, ATPC Work in Progress Paper Series, African Trade Policy Centre,

Economic Commission for Africa. 
Gutierrez de Pineres, S.A. and M. Ferrantino (1997). "Export diversification and structural dynamics in the growth process: the case of Chile”, Journal of Development Economics, Vol. 52, pp. 375-391.

Imbs, J. and R. Wacziarg (2003), “Stages of Diversification,” American Economic Review, 93, 1, 63-86. URL: http://www.jstor.org/stable/3132162 9

Hammouda, H.B., Karingi, S.N., Njuguna, A.E., and. Jallab, S.M (2006). Diversification: towards a new paradigm for Africa's development, African Trade Policy Centre (ATPC) Work in Progress, 35 Economic Commission for Africa

Berthelemy, J. and L. Soderling, (2001), The role of capital accumulation, adjustment and structural change for economic take-off: empirical evidence from African growth episodes, World Development, 29(2), pp. 323-343.

Acemoglu, D. and Zilibotti, F., 1997, "Was Prometheus unbound by chance? Risk diversification and growth", Journal of Political Economy 105, pp.709-751.

Hammouda, H.B., Karingi, S.N., Njuguna, A.E., and Sadni-Jallab (2005). Growth, productivity and diversification in Africa, citeseerx.psu.edu>viewdoc >download. Assessed on11.12.2017

Pesaran, M.H., Smith, R.J., and Shin, Y (2001). Bound testing approaches to the analysis of level relationships, Journal of applied econometrics, 289-326

Giles, D. (2013). Davegiles.blogspot.com>2013/06>ardl. Accessed on 10.12.2017

Nell, K.S (2001). The endogenous/exogenous nature of South Africa's money supply under direct and indirect monetary control measures. Journal of Post Keynesian economics, 23(2)m 313-329

AfDB Statistics Dept, COMTRADE Database (2016). (Harmonized System 2002) - UN Statistics Division www.https://.tradingeconomics.com>nigeria

World Bank (2017). World Development Indicators Online.

Central Bank of Nigeria Statistical Bulletin (2010-2016) 